\title{
"We see what we seek": A rejoinder to the responses of Amato, Eggebeen, and Osborne
}

\author{
Loren Marks \\ Brigham Young University - Provo, loren_marks@byu.edu
}

Follow this and additional works at: https://scholarsarchive.byu.edu/facpub

Part of the Other Social and Behavioral Sciences Commons

\section{Original Publication Citation}

Marks, L. (2012). "We see what we seek": Responses to the reviews of Amato, Eggebeen, and Osborne. Social Science Research, 41, 784-785.

\section{BYU ScholarsArchive Citation}

Marks, Loren, "'We see what we seek": A rejoinder to the responses of Amato, Eggebeen, and Osborne" (2012). Faculty Publications. 4876.

https://scholarsarchive.byu.edu/facpub/4876

This Peer-Reviewed Article is brought to you for free and open access by BYU ScholarsArchive. It has been accepted for inclusion in Faculty Publications by an authorized administrator of BYU ScholarsArchive. For more information, please contact ellen_amatangelo@byu.edu. 


\section{"We see what we seek": A rejoinder to the responses of Amato, Eggebeen, and Osborne}

\section{Loren Marks}

Louisiana State University, United States

In this rejoinder I adopt a conversational and less dehydrated tone, to the relief of any who labored through my full-length piece. I will be comparatively brief and, hopefully, more engaging.

An influential person in my personal and professional life has taught that as individuals, "We see what we seek." In a social science context, I am convinced that there is a measure of truth in this statement and it is this truism that, in part, makes social science so fascinating-because, as researchers, we see (and often want to see) different things.

Over the past 2 years that I have worked on "A Closer Examination...," I sought feedback from a variety of sharp minds. Academically, the dozen or so scholars I pestered represented psychology, family studies, demography, sociology, political science, social work, and law. A wide array of viewpoints all across the political spectrum was represented, and constructive criticism ranged just as widely. Adjectives included words like "enlightening" in one case and "inflammatory" in another. "A valuable contribution" that "carefully critiques," Osborne states. In his response (this issue), Eggebeen summarized, "The Marks paper reads like a legal brief: precise, careful, dry prose festooned with footnotes." One close friend offered a less tactful summary of the paper: "A new and effective cure for insomnia."

This is not the time to break into a detailed discussion of how we, as social scientists, are often like the blind men of Indostan who feel different parts of the elephant and report different experiences - however appropriate the analogy may be.

Continuing with another response, Amato (this issue) responded that the "criticisms [in the Marks article] raise two questions":

How good (or bad) is the existing evidence? And did the APA publication misrepresent this evidence.... [In response], I do not believe that the authors of the APA publication are guilty of serious misrepresentation... The [APA] statement that 'Not a single study has found children of lesbian and gay parents to be disadvantaged...' is unfortunate.... Setting aside this one intemperate statement, however, the APA publication accurately reflected the state of knowledge at that time. .

I must confess that I cringed a bit at reading the words "serious misrepresentation" and ran a word search of my document to make certain this concept was implicitly raised in the reader's mind and not an explicit allegation on my part. By comparison, Eggebeen's interpretation was that my paper "focuses on the quality of the science behind the findings that formed the basis of the official brief on this subject by the American Psychological Association." This was my intent. To borrow the title phrase of a Slife and Williams (1995) book, I wanted to know "What's behind the research?"

To recap, for one respondent the piece seems to represent an implicit accusation, for another, a careful critique. For a third respondent, "The bottom line of this review is understated, but clear: The conclusions in the APA report are unwarranted." (This is Eggebeen's interpretation of my message, not necessarily his stance.)

It is apparent that different researchers-even intelligent, prolific, and similarly trained ones-are likely to interpret the same piece quite differently. In seeking criticism from more than a dozen diverse researchers on my article, I was repeatedly humbled (and a bit chagrined) by holes and weaknesses they identified-because their criticisms were valid and required more work. . .and a wider scope of vision. Indeed, if it is true that "we see what we seek," an extension of that truism is that we tend to ignore what we do not want to see. Through the help of myriad reviewers, many of whom see and seek quite differently than I do, my article was strengthened. Even so, there are likely flaws and blind spots that remain. This is a pronounced cost of solo-authored work. There is no co-author or team of co-authors to perpetually say things like, "Loren,

E-mail address: lorenm@lsu.edu 
there is a semi-truck in your blind spot." Nor is there anyone there to hear me figuratively respond in my weaker moments, "What truck? I don't see it and I am certainly not going to write about it."

Continuing, when Amato states, "I do not believe that the authors of the APA publication are guilty of serious misrepresentation," I agree with him with one important exception. The body of the APA Brief's "Summary of Research Findings" (pp. 5-22) that I closely examined in my paper was not composed by an ideologically balanced committee of authors. It was written by a single author, an author who-like me, like any of us-has within her academic purview areas of clarity as well as blind spots. Amato goes onto state:

[T] he APA publication accurately reflected the state of knowledge at that time.... Of course, conclusions are only as strong as the evidence on which they are based, and existing studies, as both Marks and Regnerus noted, have serious limitations.

True. However, I would posit that these "serious limitations" warranted scientific consideration and examination in the solo-authored heart of the APA Brief (pp. 5-22), as opposed to a few token sentences that failed to reference, much less scientifically engage, the work of methodological experts who identified several ostensibly "fatal flaws" in the body of work, as documented in my article. Osborne puts it well: "Scholars need to be extremely clear about what...can and cannot [be] claim[ed]."

An astute reader might justifiably point out that my argument against solo-authorship is hypocritical in a solo-authored rejoinder to comments regarding my solo-authored piece. Score: Astute Reader, 2; Marks, 0. However, in the spirit of rejoinder, I offer two caveats: (a) my observations were not presented as officially representing the world's largest organization of social scientists, and (b) I invited a co-author or two, but for reasons that can be ascertained only by those possessing some common sense, no one else was willing to join me in charging into a firestorm with a squirt gun.

"Serious misrepresentation" by the APA or the Brief's author is not my charge but I certainly do claim that we have a tendency to see what we seek: and that we all have what Harvard psychologist Gilbert (2006) refers to as "blind spots in the mind's eye." I also think we can ameliorate some of these blind spots by sincerely considering points of view that differ from our own. To the serious academic, I issue a two-part invitation: (a) Read or re-read the APA Brief's "Summary of Research Findings" (there is much of value in it and it represents untold hours of work), and (b) Consider the seven concerns I raise in my paper. In doing so, some scholars may be convinced of the validity of the Brief's conclusions, with caveats (Amato). Conversely, the perception of others may be that the Emperor is not adequately clothed for the parade. Other readers may camp in the middle but adopt "more caution when drawing strong conclusions based on the available science" (cf. Eggebeen) or strive to be "extremely careful not to make claims that are unsupported by their research" (cf. Osborne). A final group, like my friend mentioned at the outset of this rejoinder, will be temporarily cured of their insomnia.

As social scientists, we have ideologies that predispose us to see some things and to ignore others. However, in making the uncomfortable effort to look closely to see more than just what we want to see, we gain in at least two respects: (a) we end up with more clarity and scope of vision, and (b) we gain an increased awareness that we do have blind spots-and this heightened awareness that we are not all-seeing fosters a healthy humility. In my experience, when I have observed this type of humility, absence of dogmatism, and genuine hunger for truth and validity in select scholars, their "lived invitation" invokes in a me a desire to be more like them. When such a person sees things differently than I do, my first internal question is not "What is wrong with them?" Instead, the initial question becomes: "If a scholar of that quality sees things differently than I do, there must be something I am missing. . what is it?"

A highlight of my experience in this exchange has been receiving careful and considerate responses to my work by premier scholars. Professors Amato, Eggebeen, and Osborne all see some things differently than I do, but as I reviewed their insightful comments, I gained a little more vision. Further, I lost nothing except another blind spot or two.

As I conclude a high-profile interchange on perhaps the most volatile social issue of our time, I am grateful for the collegiality extended to me by Amato, Eggebeen, and Osborne, I thank them respectfully for their time and effort. May we all strive to acknowledge that we tend to see what we seek, to have the humility to confess partial blindness, and to have the openness to allow others to clarify and expand our vision. Ironically, vision may be best clarified and expanded by respectful interaction with those who see the world quite differently than we do.

\section{References}

Gilbert, D., 2006. Stumbling on Happiness. Vintage, New York.

Slife, B.D., Williams, R.N., 1995. What's Behind the Research? Hidden Assumptions in the Behavioral Sciences. Sage, Thousand Oaks, CA. 